\title{
The illusion of control, the structure of prizes and the demand for football pools in Spain
}

\author{
Jaume García* and Plácido Rodríguez**
}

\author{
* Corresponding author: \\ Department of Economics and Business \\ Universitat Pompeu Fabra \\ Ramon Trias Fargas 24-26 \\ 08005 Barcelona (Spain) \\ Phone: 34935421748 \\ Fax: 34925421746 \\ e-mail: jaume.garcia@upf.edu \\ ** Department of Economics \\ Universidad de Oviedo \\ Avenida del Cristo, $\mathrm{s} / \mathrm{n}$ \\ 33071 Oviedo (Spain) \\ Phone: 34985103733 \\ Fax: 34985104871 \\ e-mail: placido@uniovi.es
}

\section{ACKNOWLEDGEMENTS}

This paper is based on the report "Las quinielas de fútbol en España: "comprar un sueño" y algo más, financed by the Liga Nacional de Fútbol Profesional". We are grateful to Angel García, Juan Prieto, Josep Lluis Raymond and the participants at the seminars at the University of Oviedo and the University of the Balearic Islands for their comments on earlier stages of this work. The first author wishes to express his gratitude for financial support from DGI grant No. BEC2002-04294-C02-02. The usual disclaimer applies. 


\begin{abstract}
Using data for all the fixtures for the seasons from 1972-73 to 2002-03, we estimate a dynamic model of demand for football pools in Spain paying attention to whether their main economic explanatory variable is the effective price of a ticket or the jackpot. Additionally, we evaluate the importance of the composition of the list of games in terms of whether First Division matches are included or not. Results show that the jackpot model is preferred to the effective price model, having important implications in terms of how the structure of the game should be changed in order to increase demand.
\end{abstract}

Keywords: Lottery, football pools, effective price, jackpot

JEL classification: D12, D80, L83 


\section{Introduction}

Football pools (La Quiniela) were introduced in Spain in the 1946-47 season. Each bet is composed of either 14 or 15 matches corresponding, in general, to Spanish First and Second Division teams. La Quiniela is a pari-mutuel game where prizes represent a share of sales revenue and players have the possibility of choosing the final result of each match from among three alternatives: home win (1), draw (X) and away win (2). As such, it shares some features with the lotto, in that both are pari-mutuel games, but La Quiniela is not a lottery in the sense that the winning combination is not the outcome of a draw but is instead related to the final result of the matches on the coupon. Consequently, players can use information about the previous performance of teams included in each fixture in order to decide which forecast $(1, X, 2)$ to choose.

For many years La Quiniela, along with the Lotería Nacional (a weekly draw) and the ONCE ${ }^{1}$ lottery (a daily draw) were the only betting games available in Spain. However, in 1986 a lotto game, Lotería Primitiva, appeared and had an important (negative) impact on the sales of La Quiniela, as happened with the British football pools (Forrest, 1999). In both games the size of the jackpot depends on sales but, given the information players have about the ex ante probabilities of the final result of any match, the number of players getting all fourteen (fifteen) forecasts right is much higher than that we would expect if the final results were completely random. This implies, given the pari-mutuel structure of both games, that prizes are larger in Lotería Primitiva than in La Quiniela, so the expected effective price of a coupon is lower in the former game, implying a higher demand.

In this paper we wish to analyse the determinants of the demand for football pools in Spain using two specifications which come from the existing empirical literature on lotto demand ${ }^{2}$, devoting special attention to the issue of which economic model is behind the empirical evidence, i.e. whether the main economic determinant of sales is the effective price or the size of the jackpot. This aspect has some relevant implications because the effect of changing either the structure of prizes or the design of the game will differ depending on the economic model 
we consider. On the other hand, we wish to measure the importance of the active role of the player in La Quiniela, which goes beyond the illusion of control in the lotto game where you just decide which numbers are chosen. In La Quiniela the player uses the information about the performance of the teams in the past in order to make the choices and this gives an extra illusion because players can show their ability and knowledge of football teams, having an extra interest in following the evolution of the matches. Finally, we also wish to measure and control the effect of other potential determinants of sales such as nominal price, addiction, seasonality, the birth of the Lotería Primitiva and whether it is weekend fixture or not.

The paper is organised as follows. In section 2 we describe the evolution of sales and revenue from the 1970-71 season up to the end of the 2003-04 season. In section 3 we present the two economic models we will consider, paying special attention to their specification and the effect of the prize structure in each case. The definition of the variables used in the empirical analysis is presented in section 4 , focusing particularly on the changes in the prize structure and their effect on the effective price. The main results are reported in section 5, whereas in section 6 we present some results from a simulation exercise in order to evaluate the performance of both models and to measure the impact on expected sales of different prize structure scenarios. The paper ends with a summary of the main conclusions.

\section{La Quiniela in Spain}

La Quiniela in Spain is managed by a public institution, Organismo Nacional de Loterías y Apuestas del Estado (ONLAE), which also operates most of the other lotteries in Spain. To win the first prize, players have to guess correctly fourteen results, with exception of the period between the start of the 1988-89 season and the end of the 2002-03 season where fifteen instead of fourteen matches were included in the coupon Pleno al 15). Until the 1988-89 season, those correctly predicting fourteen, thirteen and twelve results obtained prizes and when there were no winners of the first prize, those getting eleven right also won a prize. Since then, if there are no winners of the first prize, this money rolls over, and since the 1991-92 season, those guessing eleven results have won a prize. 
Figure 1 plots coupon sales (volume) over time since the 1970-71 season, which is the first for which official information about sales is available. There is a clear positive trend in the first period, reaching a maximum in the 1981-82 season in spite of the price changes in the 1976-77 (50\%) and 1980-81 (33.3\%) seasons. These price increases caused drops in sales but they did not affect the positive trend. The price change in the 1981-82 season (50\%) significantly reduced coupon sales but nominal revenue (Figure 2) still had a positive trend with a maximum in the 1983-84 season and remained stable in the following season, the last before the Lotería Primitiva appeared. For this whole period, real revenue (Figure 3) has no significant trend. Most of the variability observed in the series comes from the fact that not all the coupons include Spanish First Division games, in particular at the end of each season, and also because some coupons correspond to mid-week matches.

When Lotería Primitiva appeared, coupon sales and real revenue fell dramatically but nominal revenue also fell in spite of the price increase in the 1986-87 season. However, this negative trend in sales and revenue was brought under control and eliminated between the 1988-89 season, when the Pleno al 15 appeared, and the 1991-92 season. Since then coupon sales have a significant positive trend despite an increase in the price of the coupon in the 1994-95 season. This positive trend ends in the 1996-97 season and since then sales and revenue seem to have reached a steady state. In fact, apart from the time necessary for players to get used to the new system of the Pleno al 15, the number of rollovers can partly explain the differences we mention. Between the 1988-89 and 1990-91 seasons there were only 19 rollovers whereas from the 1991-92 season until last season there were 112 . The recovery generated by the Pleno al 15 seems to have been exhausted and real revenue on average for this last period represents only $55.2 \%$ of the average prior to the appearance of the Lotería Primitiva.

In the 2003-04 season there was an important change in the structure of prizes, although the proportion of revenue devoted to prizes was the same as before (55\%). The Pleno al 15 disappeared and those getting 10 results right also win a prize. We can see that the number of coupons has decreased because of a significant increase in prices (from $0.3 €$ to $0.5 €$ per 
ticket), the total revenue has increased in nominal terms $(7.93 \%)$ and also in real terms $(5.29 \%)$ compared to the previous season.

Figure 3 provides a good summary of the evolution of La Quiniela over the last decades because analysing the evolution of revenue in real terms we take into account the evolution of both sales and real prices. We can clearly identify five periods: a stationary period until the appearance of the lotto, the negative trend following it, the initial stabilisation with the Pleno al 15 , the subsequent positive trend generated by the important change in the structure of prizes (in particular, the presence of rollovers), and the final (recent) steady state period as a consequence of the exhaustion of the recovery capacity of the Pleno al 15.

Additionally, Figure 3 also points to evidence relating to the main objectives of this paper: on the one hand, the existence of rollovers during a period of significant increase in sales (observations clearly above the trend for the last seasons) hints that the structure of prizes seems to matter in terms of demand, and the other, the positive trend observed during the last seasons is more marked when First Division matches are on the coupons than when not (observations below the trend in the last seasons).

\section{Economic framework}

As we mention above, we are going to use the economic models, which have been used in the empirical literature analysing the demand for lotto. The effective price model based on the expected utility theory has been the most frequently used in this empirical literature ${ }^{3}$. Lotto tickets are treated as financial assets with risk where the prizes are understood as the return on an investment, which is the price of the ticket. The effective price of a ticket is defined as the difference between the nominal value of the ticket and the expected prize.

We are going to consider a very simple case where there is only one prize, the jackpot, which is defined as: 


$$
J=(1-\tau) A+B
$$

where $\tau$ is the take-out rate (the proportion of sales which is not devoted to prizes), A is the total number of tickets sold, with a unit price to simplify the presentation, and B is the rollover, coming from previous fixtures without winners.

The game design has an obvious influence on the probability of a ticket being a winner. For instance, in the case of lotto (6/49) the probability of having a winning ticket is known in advance (1 divided by $49 ! / 6 !(49-6)$ !) given the random choice of the numbers ${ }^{4}$. However, this is not the case in La Quiniela where this probability ex ante will be different depending on the particular signs for each match, but we will assume that there is an ex ante probability of having a winning ticket $(\pi)$ which is constant for all tickets. Consequently, the probability of generating a rollover $(P)$ (not having any winner) will be given by:

$$
P=(1-\pi)^{A}
$$

i.e., the probability of none of the bettors having a winning ticket, assuming that bets are independent. Notice that $P$ decreases with $A$ and increases with $\pi$, a measure of how easy the game is.

Following Cook and Clotfelter (1993) the expected prize (V) for a bet is the amount of the prize multiplied by the probability of having a winning ticket and divided by the expected number of winners of the jackpot. Farrell et al (1999) reinterpret this expected prize as the jackpot multiplied by the probability of having at least one winner (1-P) divided by the total sales, i.e.

$$
V=(1-P) J / A
$$

Given the definition of the jackpot $(\mathrm{J})$, the maximum prize, in expression (1), the expected prize increases with the amount of the rollover and decreases with the take-out rate. Additionally, when there is no rollover $(B=0)$ the expected prize increases with sales through $P$ but at a 
decreasing rate, tending towards $1-\tau$, i.e. the proportion of revenue devoted to prizes. Increasing sales has two effects: the prize increases because of the higher number of bettors, but at the same time the expected number of winners increases, dominating the first effect. On the other hand, when there is a rollover $(B>0)$ the expected prize increases with sales above $1-\tau$ because of $B$ being positive, reaching a maximum and then tending towards $1-\tau$. Finally, the difficulty of the game, measured by $\pi$, has a negative effect on the expected prize, although as sales tend to infinity the expected value also tends to $1-\tau$, whatever the degree of difficulty of the game.

Consequently, and as mentioned by Forrest et al (2002), the main limitation of the effective price model is that demand does not depend on the structure of prizes. If we consider a situation with several prizes, not only the jackpot, any change in the structure of prizes which does not have an effect on the actual effective price will have no effect on demand. Thus, the amount of the jackpot (even when we have a rollover) affects demand through the effective price but the same effect can be achieved by adding the rollover to a secondary prize. Empirical evidence for the lotto in the UK seems to contradict this (Forrest et al, 2002) ${ }^{5}$.

As mentioned by Sauer (1998), it is not easy to find a theoretical framework coherent with the effective price model. Bettors would be indifferent to the prize structure if they are risk neutral, but in this case they will make clearly unfair bets (expected profits are less than costs). Conslik (1993) seems to offer an explanation for the effective price model by assuming that individual preferences do not depend only on the comparison of expected utilities associated with betting or not, but have an additional element which depends on the fun generated by the game. In this context the effective price can be interpreted by the price of this fun but Conslik's model assumes that the amount of fun does not vary with the structure of prizes. This is an important element among the demand factors for La Quiniela, because the individual controls and has an influence on the bets he makes. The bettor is uses his knowledge of the teams included in the coupon when making his bet.

Forrest et al (2002) specify a model where the jackpot is the relevant economic variable determining sales. Their model is based on a previous idea by Clotfelter and Cook (1989) who 
consider that bettors are buying a hope or a dream each time they buy a ticket and this hope or dream has to do with the size of the jackpot. Thus, they propose not to use the effective price but the jackpot as the main economic variable affecting sales. In some sense the model by Golec and Tamarkin (1998) gives some theoretical support to this approach because they show that if the expected utility depends not only on the expected prize and its variance, but also on the symmetry (third moments) then bettors who are risk averse can make unfair bets. However, notice that including the third moments means implicitly including the rollovers (and therefore the jackpot) which are the basic elements generating skewness for the prizes ${ }^{6}$.

Since the effective price model and the jackpot model have different implications in terms of the policy changes in the structure of prizes, we will carry out a comparison of the performance of both models in explaining the data as an additional objective of this paper, following an approach similar to that of Forrest et al (2002).

\section{Data and variables}

The data used in the estimation exercise of this paper correspond to all the fixtures of La Quiniela from the 1972-73 until the 2002-03 season. We do not use the information on the 2003-04 season because the structure of the game and prizes has changed and we are going to use this information to validate the models we estimate. Descriptive statistics of the variables used in the estimation are presented in Table A.1 in the Appendix.

The two models we consider differ in the way prices and expected prizes are introduced in the specification. We use the effective price (EP) in one model and the jackpot $(J)$ plus the nominal price (NP) in the other.

In Table 1 we report how these three variables have been defined during the sample period and implicitly we also report when the rollover (B) was introduced (season 1988-89). We must point out that in order to calculate the expected prize we have to weight prizes associated to 14 and 15 correct guesses by the probability of having at east one winner of this prize, because 
otherwise it rolls over. This is why since the $1988-89$ season we use, when necessary, $\mathrm{P}_{14}$ and $P_{15}$. These probabilities are approximated by the proportion of fixtures with winners of the prizes of fourteen or fifteen correct guesses during the whole sample period $(0.923894$ and 0.80708 , respectively). Since the 1991-92 season, when the amount of the prize for those guessing correctly eleven results is below a certain quantity, they do not receive the amount and the total is also rolled over. This is why we introduce the probability of the prize being smaller than that quantity $\left(P_{\text {no11 }}\right)$, approximated by the proportion of fixtures with this situation $(0.964045)$. Finally, we must mention that during the 1986-87 and 1987-88 seasons ONLAE introduced a new prize for those correctly guessing all the results at half time, reducing that part of total revenue devoted to prizes for the correct guess of the end-of-match results.

Basically the changes in the price of the bet have served to keep it more or less constant in real terms, although a slight positive trend can be identified over the recent period. Of course, the last change introduced in the 2003-04 season does not fit this pattern because the price has risen from $0.3 €$ to $0.5 €$. The same comments apply to the evolution of the effective price although in this case it is important to point out the variability introduced by the rollovers, which makes them useful as instruments in the estimation of the model. Additionally, only in one fixture (fixture 42 in season 2001-02) is the effective price negative. This is because there was an important jackpot for this fixture due to a rollover and sales were not very large because there were no First Division teams in the coupon.

As we mentioned before, we think that in La Quiniela there is something other than the illusion of control, which is assumed in the lotto, because of the role played by the knowledge of the bettors about the teams involved in the coupon. This is controlled by introducing a dummy variable for the absence (presence) of First Division teams, allowing its effect to change from season to season. We also control for the absence (presence) of Second Division teams. The reference group is that composed of the fixtures where neither First nor Second Division teams are present. 
On the other hand, and as mentioned before, the appearance of the Lotería Primtiva had an important negative impact on sales of La Quiniela. We control this by introducing a dummy variable whose coefficient changes depending on the season we consider. We control in a similar way the change introduced in La Quiniela by the Pleno al 15.

Given that we are dealing with time series data we need to control for seasonality effects. We do this by introducing dummies corresponding to months, Easter week and midweek fixtures, and the first two fixtures of the season. We also control for the fact that in the 1981-82 and 1984-85 seasons there were no matches played in four fixtures because of players' strikes and the results for La Quiniela were decided by a random draw.

Finally, we take into account dynamic considerations in the set-up of the models in order to get a correct specification and to control for the effect of addiction or loyalty. We do this by introducing three lags of the endogenous variable and the average revenue of the last 43 fixtures. This last variable tries to capture the potential stability of the amount devoted to La Quiniela by bettors during one season.

\section{Empirical results}

We estimated both models (the effective price model and the jackpot model) by Instrumental Variables (IV) given that the endogenous variable (number of coupons) is included in the definition of both the effective price and the jackpot, in accordance with the definitions of these variables presented in the previous section ${ }^{7}$. We use the rollover to instrument both variables because it is correlated with both variables (it enters in a non-linear manner in the definition) and it is clearly an exogenous variable because it is determined previously.

In Table 2 we present the estimation results for both models using four different samples: the subsample from the 1972-73 season until the last fixture of the 1992-93 season (1972/73 to 1992/93) in order to estimate the effect of the appearance of the Loteria Primitiva; the subsample corresponding to the period since the introduction of the Loteria Primitiva (Loteria 
Primitiva $=1$; the subsample corresponding to the period where the Pleno al 15 prevailed (Pleno al $15=1)^{8}$; and the last period where the price has been fixed at $0.3 €($ Price $=0.3 €)$. By comparing the estimation results for these four subsamples we can evaluate the importance of the structural change in the demand for football pools in Spain since the beginning of the seventies.

We analyse the explanatory power of both models for the four subsamples using two statistics: the adjusted $R^{2}$ and the standard error of the residuals $(\sigma)$. We know that the comparison of these measures for the models is not a formal test of which model is the best specification, because the models are not nested, but in any case we think that this rough comparison gives sufficient and convincing information about how well both models explain what has happened with the football pools in this period. Looking at the results presented in Table 2 we can conclude that for all the subsamples and for both statistics, the jackpot model fits the data better than the effective price model. The explanatory power is smaller for recent periods but, at the same time, the performance of the jackpot model is much better than that of the effective price model in the last periods.

Taking into account the functional form we use where all the economic variables (sales, effective price, real price, jackpot) are in logs, short and long run elasticities for the nominal price $\left(\varepsilon_{N P}\right)$ and the rollover $\left(\varepsilon_{B}\right)$ are calculated and presented in Table 3 for all the subsamples considered.

Price elasticity is quite different depending on the specification. In the jackpot model, the preferred model, we can measure the elasticity with respect to the nominal price and this elasticity is close to -1 , except for the most recent subsample, not rejecting this null hypothesis. On the contrary, in the effective price model this elasticity is much lower in absolute value in the short run, with a substantial increase in the long run. When we consider the more recent subsample (Price $=0.3 €$ ), nominal price elasticity suffers an important reduction showing that ONLAE is not maximizing either revenue (elasticity equal to -1 ) or profits (elasticity between 1.06 and -1.12 given the marginal costs associated with each new bet) in the most recent 
period. With respect to rollover elasticity, it is quite similar in the short run for all the subsamples, being positive and significant and showing the importance of the effect of rollovers on sales.

As mentioned before, one of the differential features of La Quiniela with respect to the lotto is that the bettor has an active role when guessing the results of the matches and also some of them have additional fun when following the matches by means of the radio or TV to see how many forecasts they got made. This explains why the composition of the coupon, meaning the matches included on it, is a characteristic of the good to be consumed which is different in each fixture and can have a significant effect on sales. We distinguish three types of coupons according to the matches included: those including Spanish First Division teams, those including Second but not First Division teams, and those not including First and Second Division teams. According to the estimation results of the jackpot model fr the most recent subsample (Price $=0,3 €)$, the short run impact of the absence of First Division matches in the coupon implies a $53.47 \%$ reduction in sales ${ }^{9}$. In this case it makes sense to quantify the long run impact because that would be equivalent to the non-participation of First Division teams in La Quiniela for ever. The reduction reaches $60.26 \%$, i.e. more than $60 \%$ of the sales in standard fixtures is due to the presence of First Division teams ${ }^{10}$. This implies there must be something else in the case of the football pools apart from the fun or illusion of control, which the lotto is supposed to have.

We can summarise the results corresponding to the remaining explanatory variables in the jackpot model as follows:

Using the estimation results for the first subsample (1972/73 to 1991/92) we can conclude that the appearance of the Lotería Primitiva had a strong and significant negative effect on La Quiniela (a 36.49\% decrease in the short run). In particular, the long run effect, once the new game was consolidated, represents that sales were reduced by more than half $(50.80 \%)$. This shows an important degree of substitutability between both games, although that seems to be a long run (structural) 
effect rather than a short run one, given the available evidence about how the Loteria Primitiva is affected by the non-presence of First Division teams in the coupon and also because there is no significant effect of lotto rollovers on La Quiniela sales.

Using the subsample since the Loteria Primitiva was introduced (Loteria Primitiva $=1$ ) we can estimate the effect on sales of the change in the structure of prizes corresponding to the Pleno al 15 . We estimate a $7.68 \%$ increase per year in sales during the seasons in which Pleno al 15 generated a positive trend in sales. This also shows the positive effect of the rollover that appears with it ${ }^{11}$.

The midweek features cause a substantial reduction $(26.95 \%$ in the model estimated with the most recent subsample) on sales ${ }^{12}$. This is more or less stable throughout the whole period but, if anything, there is a reduction in absolute value. This is probably due to the new technologies introduced in the betting system by ONLAE.

There are some seasonal patterns in the evolution of sales which are worth mentioning using the estimates of the model for the most recent subsample: Easter week has a significantly negative effect $(7.41 \%)$ on sales, however this effect seems to have been reduced in the last seasons, when comparing the results for the different subsamples, as a consequence of the better betting facilities in recent years; the first fixtures, which usually correspond to the end of August or the beginning of September, have smaller sales; and there seems to be some "fatigue" among bettors as the season reaches its end.

On the other hand, all the estimated models have a dynamic specification because of both econometric and economic reasons. In particular, this allows us to capture the effect of bettors' loyalty, as in the case of the analysis of attendance. This is what is usually known as "addiction". We specify a model of myopic addiction as considered by Becker and Murphy (1988) where only lags of the endogenous variable appear as explanatory variables. The estimated effect of addiction, obtained as the sum of the coefficients of the lag endogenous variables varies from 0.171 to 0.360 depending on the subsample considered (from 0.226 to 0.485 in the case of the effective price model). These values are similar to those obtained by 
Farrell et al (1999) for the British lotto but slightly smaller than 0.45, which is the addiction effect found by Becker et al (1994) for the demand for tobacco.

Finally, it should be highlighted that all these effects are qualitatively the same if we consider the effective price model.

\section{Simulation results}

We can use the estimated models both to predict sales and to simulate the effect of changes in the structure of the game and of the prizes on the total number of coupons. This will allow us to compare the predictive performance of the two different specifications we have estimated and to carry out a simulation exercise for the last season (2003-04) using both specifications. In fact, in that season the structure of the game changed (the Pleno al 15 disappeared) and also a new structure of prizes was introduced. It is interesting therefore to look at how other alternative changes in the structure of the game and in prizes would have affected sales and compare these simulation results with actual evidence.

In order to carry out the simulation exercises we use both models estimated for the most recent sample (Price $=0.3 €$ ). This makes the model less dependent on the structural changes since the seventies. We make both static and dynamic predictions for all the fixtures of the 2003-04 season. For the static predictions we use the observed values for the lagged endogenous variables, whereas for the dynamic predictions we use the predicted values. In some sense, the static predictions can be interpreted as short-run predictions (next period predictions), whereas the dynamic predictions can be thought of as being long-run ones (predictions are made as if the season were about to start). We take into account the non-linearities of the models in both simulation exercises.

By looking at the results in Table 5 we can confirm the result we mentioned before concerning the fact that the jackpot model is preferred over the effective price model. The mean of the predictions for last season's fixtures is closer to the actual sales in the case of the jackpot 
model. Moreover, when looking at the absolute value of the errors, the mean is smaller in the case of the jackpot model for both the static and the dynamic versions.

The second simulation exercise evaluates the expected effect on sales of two different scenarios in terms of the structure of the game and prizes different from the one adopted in season 2003-04. Scenario 1 consists of maintaining the same structure we had in the previous season, i.e. the Pleno al 15. This will allow us to evaluate the number of coupons sold if there had been no changes in the structure. Scenario 2 consists of a situation where the previous system is not changed except that the prize for those correctly guessing eleven results is eliminated, adding the $10 \%$ of revenue devoted to this prize to the jackpot.

The results of this simulation exercise are also presented in Table 5. Under the previous system (Scenario $\pitchfork$ and according to the jackpot model, sales and, consequently, revenue would increase between $11.66 \%$ and $15.42 \%$ depending on whether we consider static or dynamic predictions. This is because under the new system the jackpot is reduced. To the contrary, the effective price model would predict less sales because the effective price increases with respect to that of the previous system because the probability of having at least one bettor guessing all fifteen results correctly is less than one whereas that corresponding to ten results is one. This small increase in the effective price means that, given the negative (and less than one in absolute value) price elasticity, the decrease is translated into lower revenue.

These results emphasise the consequences on sales of different specifications of the structure of the game and prizes. At the same time, these results point out that, although actual revenue has increased this season, this is basically due to the increase of the price of the ticket and this increase in revenue is smaller than that which would be generated in the case of not changing the structure.

Finally, under Scenario 2 (i.e., eliminating the prize for those guessing eleven correctly and adding it to the jackpot) sales had increased between $18.30 \%$ and $24.42 \%$ using the jackpot 
model, depending on the type of forecast. The effective price model had predicted a small decrease in sales and, consequently, in revenue.

\section{Conclusions}

In this paper we try to identify the main determinants of the evolution of sales for the Spanish football pools (La Quiniela). Using data corresponding to the fixtures from the 1972-73 to the 2002-03 seasons we estimated a demand equation in an attempt to identify whether the effective price or the jackpot are the variables which better capture the effect of the structure of prizes in order to explain the evolution of sales and revenue we observe. The evidence from the estimation of the models and from the prediction exercise carried out for the present season allow us to conclude that the jackpot model better explains sales in the case of La Quiniela. This has important implications in terms of how the changes introduced to the game and to the prizes will affect sales. In particular, we conclude that the change introduced in the present season by eliminating the Pleno al 15 (reducing the jackpot) is reducing revenue compared to what would be expected if the previous system had been maintained.

On the other hand, we have tried to quantify the importance of the composition of the coupon (i.e. which teams are present) in explaining sales. This is capturing something else in La Quiniela apart from the illusion of control present in the lotto. The reduction implied by the nonpresence of First Division teams is greater than $60 \%$.

This research could be extended by simultaneously analysing the demand for other games managed by the ONLAE, due to the potential substitutability ${ }^{13}$ between them. Additionally, it would be interesting to analyse the separability of the expenditure on these games by families with respect to other types of expenditures, in order to be more precise about the implications of changing the structure of the game and that of the prizes. 


\section{References}

Becker, G.S. and K.M. Murphy (1988) A Theory of Rational Addiction, Journal of Political Economy, 96, 675-750

Becker, G.S., M. Grossman and K.M. Murphy (1994) An Empirical Analysis of Cigarette Addiction, American Economic Review, 84, 396-418

Beenstock, M. and G. Szpiro (2002) Specification Search in Nonlinear Time-Series Models Using the Genetic Algorithm, Journal of Economic Dynamics and Control, 26, 811.835

Clotfelter, C.T. and P.J. Cook (1989) Selling Hope: State Lotteries in America, Cambridge: Harvard University Press

Clotfelter, C.T. and P.J. Cook (1990) On the Economics of State Lotteries, Journal of Economic Perspectives, 4, 105-119

Conslik, J. (1993) The Utility of Gambling, Journal of Risk and Uncertainty, 6, 255-275

Cook, P.J. and C.T. Clotfelter (1993) The Peculiar Scale Economies of Lotto, American Economic Review, 83, 634-643

Farrell, L., G. Lanot, R. Hartley and I. Walker (2000) The Demand for Lotto: The Role of Conscious Selection, Journal of Business and Economic Statistics, 18, 228-241

Farrell, L., E. Morgenroth and I. Walker (1999) A Time-Series Analysis of U.K. Lottery Sales: Long Run and Short Run Elasticities, Oxford Bulletin of Economics and Statistics, 61, $513-526$

Forrest, D. (1999) The Past and Future of British Football Pools, Journal of Gambling Studies, 15, $161-176$ 
Forrest, D., O.D. Gulley and R. Simmons (2000) Elasticity of Demand of National Lottery Tickets, National Tax Journal, 53, 853-863

Forrest, D., O.D. Gulley and R. Simmons (2004) Substitution between games in the UK national lottery, Applied Economics, 36, 645-651

Forrest, D. and R. Simmons (2003) Time Series Modelling of Lotto Demand, in L.V. Williams (ed.) The Economics of Gambling, Londres: Routledge

Forrest, D., R. Simmons and N. Chesters (2002) Buying a Dream: Alternative Models of Demand for Lotto, Economic Inquiry, 40, 485-496

García, J. and P. Rodríguez (2002) The Determinants of Football Match Attendance Revisited: Evidence from the Spanish Football League, Journal of Sports Economics, 3, 18-38.

Garrett, T.A. and R.S. Sobel (1999) Gamblers Favor Skewness, not Risk: Further Evidence from United States' Lottery Games, Economics Letters, 63, 85-90

Golec, J. and M. Tamarkin (1998) Bettors Love Skewness, not Risk, at the Horse Track, Journal of Political Economy, 106, 205-225

Gulley, O.D. and F.A. Scott, jr (1993) The Demand for Wagering for State-Operated Lottery Games, National Tax Journal, 45, 13-22

Purfield, C. and P.J. Waldron (1999) Gambling on Lotto Numbers: Testing for Substitutability or Complementarity Using Semi-Weekly Turnover Data, Oxford Bulletin of Economics and Statistics, 61, 527-544

Sauer, R.D. (1998) The Economics of Wagering Markets, Journal of Economic Literature, 36, 2021-2064 
Scott, F.A. jr. and O.D. Gulley (1995) Rationality and Efficiency in Lotto Markets, Economic Inquiry, 33, 175-188

Walker, I. (1998) The Economic Analysis of Lotteries, Economic Policy, 13, 359-392

Walker, I. and J. Young (2001) An Economist's Guide to Lottery Design, Economic Journal, 111, F701-F722 


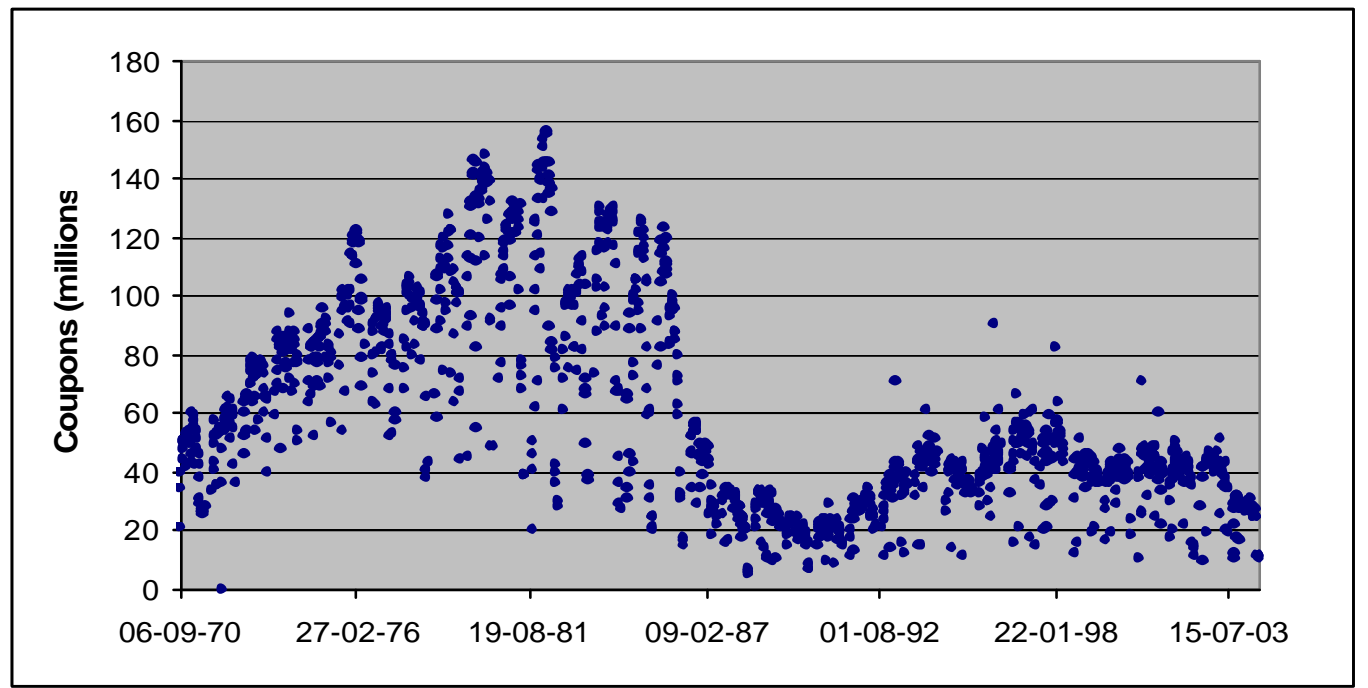

Figure 1 Number of coupons

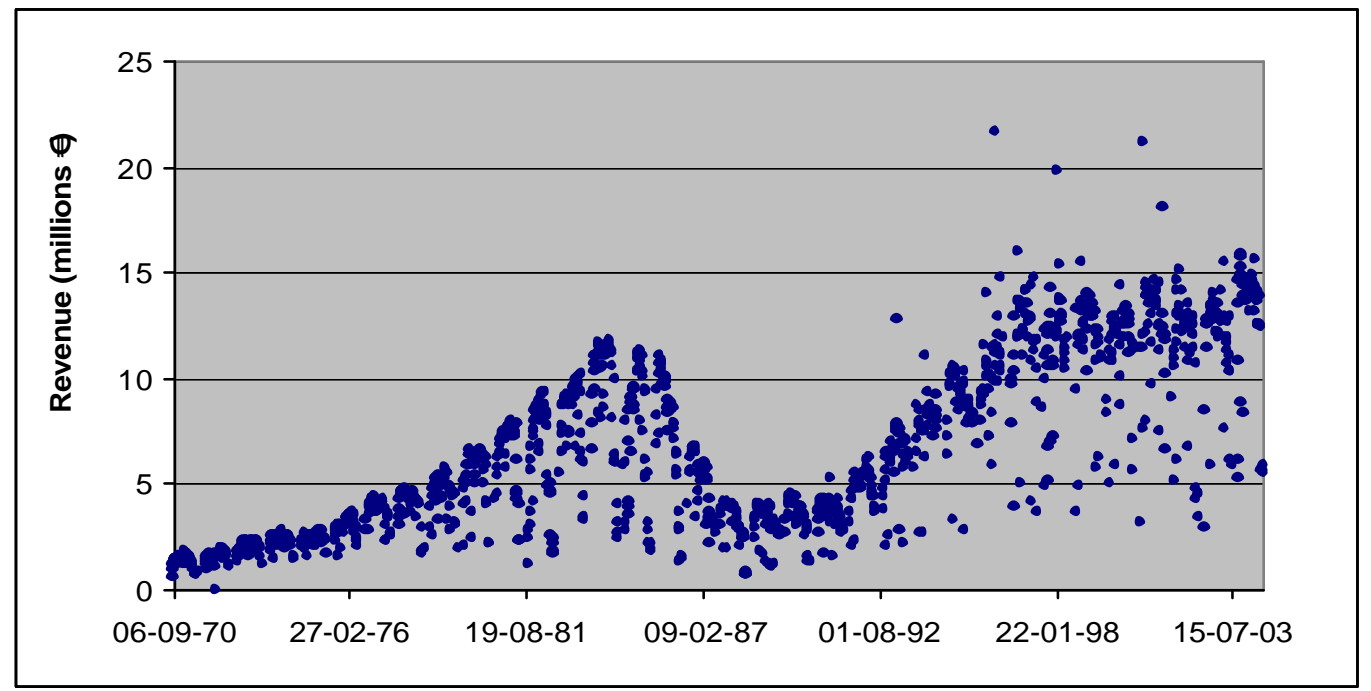

Figure 2 Revenue (nominal)

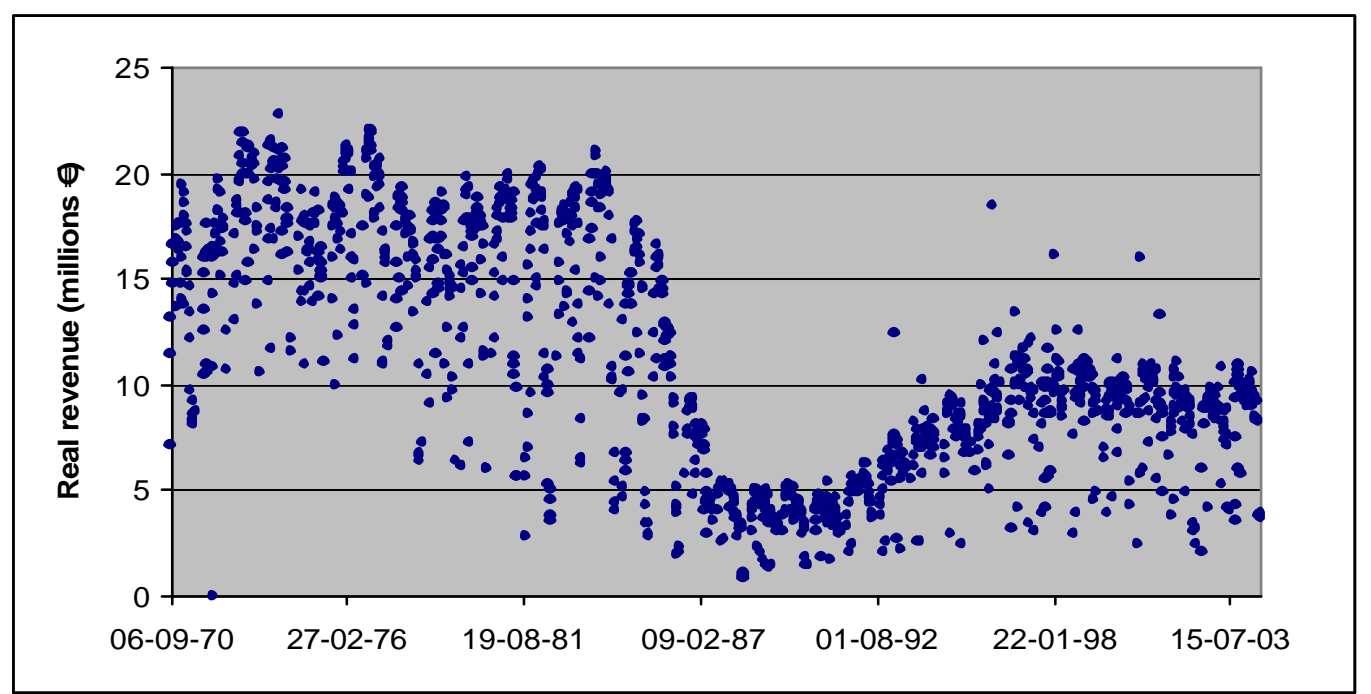

Figure 3 Revenue (real) 
Table 1: Definition of the effective price, the jackpot and the nominal price

\begin{tabular}{llll}
\hline Seasons & Effective price & Jackpot \\
\hline $1972-73$ to $1984-85$ & $E P=N P-0.55 R$ & $J=(0.55 / 3) R$ \\
$1985-86$ & $E P=N P-0.50325 R$ & $J=(0.50325 / 3) R$ & Nominal price \\
$1986-87$ to $1987-88$ & $E P=N P-0.50325 R$ & $J=(0.44034375 / 3) R+P_{\text {noD }} 0.06290625 R$ & $0.12 €$ to $0.18 €$ \\
$1988-89$ to $1990-91$ & $E P=N P-\left(\left(0.30 R+P_{14} 0.15 R+P_{15}(0.10 R+B)\right) / A\right)$ & $J=0.25 R+B$ & $0.09 €$ to $0.12 €$ \\
$1991-92$ to $2002-03$ & $E P=N P-\left(\left(P_{n 011} 0.10 R+0.20 R+P_{14} 0.15 R+P(5)(0.10 R+B)\right) / A\right)$ & $J=0.25 R+B$
\end{tabular}


Table 2: Estimation results for the demand equation (La Quiniela) (Dependent variable: Number of coupons sold (log))

\begin{tabular}{|c|c|c|c|c|c|c|c|c|}
\hline & \multicolumn{2}{|c|}{$1972 / 73$ to $1991 / 92$} & \multicolumn{2}{|c|}{ Loteria Primitiva $=1$} & \multicolumn{2}{|c|}{ Pleno al $15=1$} & \multicolumn{2}{|c|}{ Price $=0.3 €$} \\
\hline & Jackpot & $\begin{array}{l}\text { Effective } \\
\text { price }\end{array}$ & Jackpot & $\begin{array}{c}\text { Effective } \\
\text { price }\end{array}$ & Jackpot & $\begin{array}{l}\text { Effective } \\
\text { price }\end{array}$ & Jackpot & $\begin{array}{c}\text { Effective } \\
\text { price }\end{array}$ \\
\hline Nominal price ${ }^{1}(\log )$ & $\begin{array}{l}-0.895 \\
(8.31)\end{array}$ & & $\begin{array}{l}-0.942 \\
(6.73)\end{array}$ & & $\begin{array}{c}-0.792 \\
(17.64)\end{array}$ & & $\begin{array}{l}-0.358 \\
(3.52)\end{array}$ & \\
\hline Nominal price $(\mathrm{t}-1)(\mathrm{log})$ & $\begin{array}{l}0.276 \\
(2.53)\end{array}$ & & $\begin{array}{l}0.164 \\
(1.15)\end{array}$ & & & & & \\
\hline Effective price ${ }^{1}(\log )$ & & $\begin{array}{c}-0.468 \\
(15.36)\end{array}$ & & $\begin{array}{l}-0.570 \\
(21.50)\end{array}$ & & $\begin{array}{c}-0.559 \\
(20.88)\end{array}$ & & $\begin{array}{l}-0.482 \\
(9.86)\end{array}$ \\
\hline Jackpot $^{1}(\log )$ & $\begin{array}{c}0.239 \\
(8.98)\end{array}$ & & $\begin{array}{c}0.266 \\
(22.73)\end{array}$ & & $\begin{array}{c}0.266 \\
(23.01)\end{array}$ & & $\begin{array}{c}0.270 \\
(14.80)\end{array}$ & \\
\hline Sales (t-1) (log) & $\begin{array}{c}0.217 \\
(11.80)\end{array}$ & $\begin{array}{c}0.285 \\
(12.65)\end{array}$ & $\begin{array}{c}0.201 \\
(11.25)\end{array}$ & $\begin{array}{c}0.291 \\
(12.18)\end{array}$ & $\begin{array}{l}0.193 \\
(9.85)\end{array}$ & $\begin{array}{c}0.290 \\
(11.08)\end{array}$ & $\begin{array}{l}0.171 \\
(5.57)\end{array}$ & $\begin{array}{l}0.226 \\
(5.33)\end{array}$ \\
\hline Sales (t-2) (log) & $\begin{array}{l}0.101 \\
(5.50)\end{array}$ & $\begin{array}{l}0.143 \\
(5.91)\end{array}$ & $\begin{array}{l}0.056 \\
(3.01)\end{array}$ & $\begin{array}{l}0.091 \\
(3.55)\end{array}$ & $\begin{array}{l}0.054 \\
(2.68)\end{array}$ & $\begin{array}{l}0.093 \\
(3.40)\end{array}$ & & \\
\hline Sales (t-3) (log) & $\begin{array}{l}0.042 \\
(2.41)\end{array}$ & $\begin{array}{l}0.057 \\
(2.51)\end{array}$ & $\begin{array}{l}0.057 \\
(3.18)\end{array}$ & $\begin{array}{l}0.079 \\
(3.25)\end{array}$ & $\begin{array}{l}0.053 \\
(2.77)\end{array}$ & $\begin{array}{l}0.071 \\
(3.01)\end{array}$ & & \\
\hline $\begin{array}{l}\text { Sales }(t-1)(\log ) \times \text { Absence of } 1 \text { st Division teams }{ }^{2}(t-1) \times \text { Presence of } 1 \mathrm{st} \\
\text { Division teams }\end{array}$ & $\begin{array}{l}0.003 \\
(4.12)\end{array}$ & $\begin{array}{l}0.004 \\
(4.16)\end{array}$ & $\begin{array}{l}0.008 \\
(6.92)\end{array}$ & $\begin{array}{l}0.012 \\
(7.53)\end{array}$ & $\begin{array}{l}0.008 \\
(5.88)\end{array}$ & $\begin{array}{l}0.012 \\
(6.76)\end{array}$ & $\begin{array}{l}0.007 \\
(3.42)\end{array}$ & $\begin{array}{l}0.009 \\
(3.37)\end{array}$ \\
\hline $\begin{array}{l}\text { Sales }(t-2)(\log ) \times \text { Absence of } 1 \text { st Division Teams }{ }^{2}(t-2) \times \text { Presence of } 1 \text { st } \\
\text { Division teams }\end{array}$ & $\begin{array}{l}0.001 \\
(1.75)\end{array}$ & $\begin{array}{l}0.002 \\
(1.80)\end{array}$ & $\begin{array}{l}0.002 \\
(1.46)\end{array}$ & $\begin{array}{l}0.003 \\
(1.81)\end{array}$ & $\begin{array}{l}0.001 \\
(0.96)\end{array}$ & $\begin{array}{l}0.003 \\
(1.47)\end{array}$ & & \\
\hline $\begin{array}{l}\text { Sales }(t-3)(\log ) \times \text { Absence of } 1 \text { st Division teams }{ }^{2}(t-2) \times \text { Presence of } 1 \text { st } \\
\text { Division teams }\end{array}$ & $\begin{array}{l}0.001 \\
(1.87)\end{array}$ & $\begin{array}{l}0.002 \\
(1.94)\end{array}$ & $\begin{array}{l}0.004 \\
(3.48)\end{array}$ & $\begin{array}{l}0.006 \\
(3.64)\end{array}$ & $\begin{array}{l}0.004 \\
(2.90)\end{array}$ & $\begin{array}{l}0.006 \\
(3.23)\end{array}$ & & \\
\hline Average revenue in last 43 fixtures $(\log )$ & $\begin{array}{l}0.228 \\
(6.60\end{array}$ & $\begin{array}{l}0.281 \\
(6.50)\end{array}$ & $\begin{array}{c}0.372 \\
(14.76)\end{array}$ & $\begin{array}{c}0.474 \\
(15.76)\end{array}$ & $\begin{array}{c}0.371 \\
(12.98)\end{array}$ & $\begin{array}{c}0.459 \\
(14.09)\end{array}$ & & \\
\hline Lotería Primitiva ${ }^{2}$ & $\begin{array}{l}0.911 \\
(3.43)\end{array}$ & $\begin{array}{l}1.524 \\
(4.41)\end{array}$ & & & & & & \\
\hline Lotería Primitiva $^{2} \times$ Season $^{3}$ & $\begin{array}{c}-0.065 \\
(3.65)\end{array}$ & $\begin{array}{l}-0.107 \\
(4.61)\end{array}$ & & & & & & \\
\hline
\end{tabular}




\begin{tabular}{|c|c|c|c|c|c|c|c|c|}
\hline Absence of 1 st Division teams ${ }^{2}$ & $\begin{array}{l}-0.267 \\
(10.92)\end{array}$ & $\begin{array}{l}-0.350 \\
(11.1)\end{array}$ & $\begin{array}{l}-0.493 \\
(11.68\end{array}$ & $\begin{array}{l}-0.606 \\
(9.74)\end{array}$ & $\begin{array}{l}-0.648 \\
(9.91)\end{array}$ & $\begin{array}{l}-0.841 \\
(9.35)\end{array}$ & $\begin{array}{l}-0.765 \\
(15.21)\end{array}$ & $\begin{array}{l}-1.041 \\
(13.66)\end{array}$ \\
\hline $\begin{array}{c}\text { Absence of } 1 \text { st Division teams }{ }^{2} x \\
x \text { Season }\end{array}$ & $\begin{array}{c}-0.020 \\
(11.23)\end{array}$ & $\begin{array}{c}-0.026 \\
(12.27)\end{array}$ & $\begin{array}{l}-0.009 \\
(4.50)\end{array}$ & $\begin{array}{l}-0.015 \\
(5.21)\end{array}$ & $\begin{array}{c}-0.004 \\
(1.30)\end{array}$ & $\begin{array}{l}-0.006 \\
(1.61)\end{array}$ & & \\
\hline $\begin{array}{l}\text { Absence of } 1 \text { st Division teams }{ }^{2} x \\
x \text { Presence of 2nd Division teams }\end{array}$ & $\begin{array}{c}0.211 \\
(12.10)\end{array}$ & $\begin{array}{c}0.275 \\
(13.44)\end{array}$ & $\begin{array}{l}0.198 \\
(8.75)\end{array}$ & $\begin{array}{l}0.269 \\
(8.43)\end{array}$ & $\begin{array}{l}0.196 \\
(7.58)\end{array}$ & $\begin{array}{l}0.258 \\
(6.96)\end{array}$ & $\begin{array}{l}0.226 \\
(4.64)\end{array}$ & $\begin{array}{l}0.288 \\
(3.74)\end{array}$ \\
\hline Pleno al $15^{2}$ & $\begin{array}{l}-1.504 \\
(4.82)\end{array}$ & $\begin{array}{l}-2.184 \\
(5.39)\end{array}$ & $\begin{array}{l}-0.725 \\
(3.65)\end{array}$ & $\begin{array}{l}-1.184 \\
(4.73)\end{array}$ & & & & \\
\hline Pleno al $15^{2} \times$ Season $^{3}$ & $\begin{array}{l}0.084 \\
(4.66)\end{array}$ & $\begin{array}{l}0.131 \\
(5.67)\end{array}$ & $\begin{array}{l}0.085 \\
(5.41)\end{array}$ & $\begin{array}{l}0.074 \\
(4.50)\end{array}$ & & & & \\
\hline Easter week $^{2}$ & $\begin{array}{l}-0.158 \\
(7.93)\end{array}$ & $\begin{array}{l}-0.208 \\
(8.22)\end{array}$ & $\begin{array}{l}-0.109 \\
(5.62)\end{array}$ & $\begin{array}{l}-0.150 \\
(5.60)\end{array}$ & $\begin{array}{l}-0.108 \\
(5.20)\end{array}$ & $\begin{array}{l}-0.148 \\
(5.20)\end{array}$ & $\begin{array}{l}-0.077 \\
(2.23)\end{array}$ & $\begin{array}{r}-0.113 \\
(2.42)\end{array}$ \\
\hline Midweek fixture $^{2}$ & $\begin{array}{l}-0.353 \\
(7.38)\end{array}$ & $\begin{array}{l}-0.458 \\
(7.47)\end{array}$ & $\begin{array}{l}-0.333 \\
(14.48)\end{array}$ & $\begin{array}{l}-0.450 \\
(14.65)\end{array}$ & $\begin{array}{l}-0.348 \\
(14.76)\end{array}$ & $\begin{array}{l}-0.471 \\
(14.98)\end{array}$ & $\begin{array}{c}-0.314 \\
(10.17)\end{array}$ & $\begin{array}{l}-0.430 \\
(10.64)\end{array}$ \\
\hline Fixture $1^{2}$ & $\begin{array}{l}-0.036 \\
(1.43)\end{array}$ & $\begin{array}{l}-0.065 \\
(2.11)\end{array}$ & $\begin{array}{c}-0.153 \\
(7.01)\end{array}$ & $\begin{array}{c}-0.222 \\
(7.94)\end{array}$ & $\begin{array}{c}-0.194 \\
(8.89)\end{array}$ & $\begin{array}{c}-0.266 \\
(8.89)\end{array}$ & $\begin{array}{c}-0.193 \\
(4.99)\end{array}$ & $\begin{array}{c}-0.259 \\
(5.01)\end{array}$ \\
\hline Fixture $2^{2}$ & $\begin{array}{l}-0.029 \\
(1.22)\end{array}$ & $\begin{array}{c}-0.036 \\
(1.18)\end{array}$ & $\begin{array}{l}-0.038 \\
(1.76)\end{array}$ & $\begin{array}{r}-0.051 \\
(1.74)\end{array}$ & $\begin{array}{l}-0.054 \\
(2.34)\end{array}$ & $\begin{array}{c}-0.076 \\
(2.39)\end{array}$ & $\begin{array}{l}-0.105 \\
(2.91)\end{array}$ & $\begin{array}{c}-0.153 \\
(3.08)\end{array}$ \\
\hline Draw $^{2}$ & $\begin{array}{c}-0.426 \\
(9.54)\end{array}$ & $\begin{array}{l}-0.548 \\
(9.78)\end{array}$ & & & & & & \\
\hline Season $^{3}$ & $\begin{array}{c}-0.032 \\
(6.46)\end{array}$ & $\begin{array}{c}-0.039 \\
(6.31)\end{array}$ & $\begin{array}{l}-0.050 \\
(4.39)\end{array}$ & $\begin{array}{l}-0.088 \\
(5.72)\end{array}$ & $\begin{array}{l}-0.010 \\
(4.92)\end{array}$ & $\begin{array}{l}-0.014 \\
(4.81)\end{array}$ & & $\begin{array}{c}-0.012 \\
(2.34)\end{array}$ \\
\hline \multicolumn{9}{|l|}{ Month ${ }^{4}:$} \\
\hline January $^{2}$ & $\begin{array}{c}0.122 \\
(6.47)\end{array}$ & $\begin{array}{l}0.155 \\
(6.67)\end{array}$ & $\begin{array}{l}0.085 \\
(5.41)\end{array}$ & $\begin{array}{l}0.105 \\
(5.01)\end{array}$ & $\begin{array}{c}0.083 \\
(5.04)\end{array}$ & $\begin{array}{l}0.100 \\
(4.48)\end{array}$ & $\begin{array}{l}0.080 \\
(3.14)\end{array}$ & $\begin{array}{l}0.117 \\
(3.39)\end{array}$ \\
\hline February ${ }^{2}$ & $\begin{array}{l}0.136 \\
(6.92)\end{array}$ & $\begin{array}{c}0.172 \\
(7.08)\end{array}$ & $\begin{array}{c}0.102 \\
(6.16)\end{array}$ & $\begin{array}{l}0.129 \\
(5.85)\end{array}$ & $\begin{array}{l}0.101 \\
(5.86)\end{array}$ & $\begin{array}{c}0.125 \\
(5.39)\end{array}$ & $\begin{array}{l}0.097 \\
(3.71)\end{array}$ & $\begin{array}{l}0.140 \\
(3.93)\end{array}$ \\
\hline $\mathrm{March}^{2}$ & $\begin{array}{l}0.119 \\
(6.17)\end{array}$ & $\begin{array}{l}0.152 \\
(6.35)\end{array}$ & $\begin{array}{c}0.084 \\
(5.14)\end{array}$ & $\begin{array}{l}0.106 \\
(4.83)\end{array}$ & $\begin{array}{l}0.083 \\
(4.84)\end{array}$ & $\begin{array}{l}0.100 \\
(4.34)\end{array}$ & $\begin{array}{l}0.117 \\
(4.42)\end{array}$ & $\begin{array}{l}0.161 \\
(4.49)\end{array}$ \\
\hline April $^{2}$ & $\begin{array}{l}0.093 \\
(5.08)\end{array}$ & $\begin{array}{l}0.119 \\
(5.14)\end{array}$ & $\begin{array}{l}0.056 \\
(3.54)\end{array}$ & $\begin{array}{l}0.073 \\
(3.37)\end{array}$ & $\begin{array}{l}0.063 \\
(3.79)\end{array}$ & $\begin{array}{l}0.080 \\
(3.50)\end{array}$ & $\begin{array}{l}0.075 \\
(2.86)\end{array}$ & $\begin{array}{l}0.105 \\
(2.93)\end{array}$ \\
\hline
\end{tabular}




\begin{tabular}{|c|c|c|c|c|c|c|c|c|}
\hline May $^{2}$ & $\begin{array}{l}0.017 \\
(1.06)\end{array}$ & $\begin{array}{l}0.021 \\
(0.97)\end{array}$ & $\begin{array}{l}0.005 \\
(0.35)\end{array}$ & $\begin{array}{r}-0.001 \\
(0.03)\end{array}$ & $\begin{array}{c}0.018 \\
(1130)\end{array}$ & $\begin{array}{l}0.016 \\
(0.69)\end{array}$ & $\begin{array}{l}0.023 \\
(0.89)\end{array}$ & $\begin{array}{l}0.023 \\
(0.64)\end{array}$ \\
\hline September ${ }^{2}$ & $\begin{array}{l}0.152 \\
(7.65)\end{array}$ & $\begin{array}{l}0.198 \\
(7.99)\end{array}$ & $\begin{array}{l}0.082 \\
(5.23)\end{array}$ & $\begin{array}{l}0.112 \\
(5.19)\end{array}$ & $\begin{array}{l}0.082 \\
(4.87)\end{array}$ & $\begin{array}{l}0.110 \\
(4.76)\end{array}$ & $\begin{array}{l}0.037 \\
(1.54)\end{array}$ & $\begin{array}{c}0.063 \\
(1.91)\end{array}$ \\
\hline October $^{2}$ & $\begin{array}{l}0.157 \\
(8.07)\end{array}$ & $\begin{array}{l}0.201 \\
(8.47)\end{array}$ & $\begin{array}{l}0.123 \\
(7.55)\end{array}$ & $\begin{array}{l}0.157 \\
(7.30)\end{array}$ & $\begin{array}{l}0.123 \\
(7.33)\end{array}$ & $\begin{array}{l}0.155 \\
(6.90)\end{array}$ & $\begin{array}{l}0.101 \\
(3.94)\end{array}$ & $\begin{array}{l}0.149 \\
(4.30)\end{array}$ \\
\hline November $^{2}$ & $\begin{array}{l}0.160 \\
(8.05)\end{array}$ & $\begin{array}{l}0.203 \\
(8.41)\end{array}$ & $\begin{array}{l}0.121 \\
(7.23)\end{array}$ & $\begin{array}{l}0.151 \\
(6.86)\end{array}$ & $\begin{array}{l}0.118 \\
(6.75)\end{array}$ & $\begin{array}{l}0.142 \\
(6.16)\end{array}$ & $\begin{array}{l}0.114 \\
(4.32)\end{array}$ & $\begin{array}{l}0.160 \\
(4.49)\end{array}$ \\
\hline December $^{2}$ & $\begin{array}{l}0.107 \\
(5.48)\end{array}$ & $\begin{array}{l}0.134 \\
(5.35)\end{array}$ & $\begin{array}{l}0.078 \\
(4.59)\end{array}$ & $\begin{array}{l}0.095 \\
(4.18)\end{array}$ & $\begin{array}{l}0.082 \\
(4.60)\end{array}$ & $\begin{array}{l}0.096 \\
(4.02)\end{array}$ & $\begin{array}{l}0.096 \\
(3.54)\end{array}$ & $\begin{array}{l}0.137 \\
(3.71)\end{array}$ \\
\hline Constant & $\begin{array}{l}0.085 \\
(0.15)\end{array}$ & $\begin{array}{l}0.969 \\
(1.29)\end{array}$ & $\begin{array}{l}-3.105 \\
(5.97)\end{array}$ & $\begin{array}{l}-2.428 \\
(3.90)\end{array}$ & $\begin{array}{l}-3.675 \\
(9.07)\end{array}$ & $\begin{array}{c}-3.268 \\
(7.64)\end{array}$ & $\begin{array}{l}8.301 \\
(9.59)\end{array}$ & $\begin{array}{l}10.516 \\
(12.74)\end{array}$ \\
\hline Adjusted $R^{2}$ & 0.987 & 0.977 & 0.973 & 0.949 & 0.966 & 0.935 & 0.946 & 0.896 \\
\hline ? (standard error of the regression) & 0.078 & 0.104 & 0.075 & 0.104 & 0.073 & 0.101 & 0.070 & 0.096 \\
\hline Breusch-Godfrey autocorrelation test ( $p$-value) & 0.000 & 0.000 & 0.098 & 0.268 & 0.208 & 0.622 & 0.529 & 0.413 \\
\hline $\mathrm{Q}(4)$ autocorrelation test (p-value) & 0.000 & 0.000 & 0.113 & 0.213 & 0.135 & 0.635 & 0.168 & 0.332 \\
\hline Number of observations & 814 & 814 & 727 & $726^{5}$ & 605 & $604^{5}$ & 210 & $209^{5}$ \\
\hline Estimation method & $\mathrm{N}^{6}$ & $\mathrm{~N}^{6}$ & $\mathrm{~N}^{6}$ & $\mathrm{~N}^{6}$ & $\mathrm{~N}^{6}$ & $\mathrm{~N}^{6}$ & $\mathrm{~N}^{6}$ & $\mathrm{~N}^{6}$ \\
\hline
\end{tabular}

Notes: "t" statistics in absolute value in brackets

Variables in real terms

2 Dummy variables (equal to 1 when the observation has a particular attribute associated to the dummy and equal to 0 otherwise)

${ }^{3}$ Variable defined as the difference between the starting year of each season minus 1970

${ }_{5}^{4}$ Reference group: July and September
${ }_{6}^{6}$ We use one observation less to estimate the effective price model because in fixture 42 of the season $2001-02$ the effective price was negative and variables are defined in logs.

${ }^{6}$ Instrumental Variables 
Table 3: Nominal price and rollover elasticity

\begin{tabular}{|c|c|c|c|c|c|c|c|c|}
\hline & \multicolumn{4}{|c|}{ Jackpot model } & \multicolumn{4}{|c|}{ Effective price model } \\
\hline & \multicolumn{2}{|c|}{$\varepsilon_{\mathrm{NP}}$} & \multicolumn{2}{|c|}{$\varepsilon_{B}$} & \multicolumn{2}{|c|}{$\varepsilon_{\mathrm{NP}}$} & \multicolumn{2}{|c|}{$\varepsilon_{B}$} \\
\hline & s.r. & I.r. & s.r. & I.r. & s.r. & I.r. & s.r. & I.r. \\
\hline $1972-73$ to $1992-93$ & -0.877 & -0.921 & 0.109 & 0.350 & -0.537 & -0.876 & 0.130 & 0.391 \\
\hline Lotería Primitiva $=1$ & -0.931 & -1.607 & 0.124 & 0.683 & -0.587 & -1.125 & 0.151 & 0.738 \\
\hline Pleno al $15=1$ & -0.752 & -1.552 & 0.124 & 0.622 & -0.576 & -1.081 & 0.152 & 0.694 \\
\hline Price $=0.3 €$ & -0.231 & -0.291 & 0.126 & 0.158 & -0.500 & -0.686 & 0.134 & 0.166 \\
\hline
\end{tabular}

Table 4: Simulation of the current and alternative scenarios for the structure of the game and prizes for the season 2003-04

\begin{tabular}{lcccccc}
\hline & \multicolumn{2}{c}{ Current situation } & \multicolumn{2}{c}{ Scenario 1 } & \multicolumn{2}{c}{ Scenario 2 } \\
\hline & Forecast & $\begin{array}{c}\text { Absolute } \\
\text { error }\end{array}$ & Forecast & $\%$ & Forecast & $\%$ \\
Actual sales & 25267.2 & & & & & \\
& & & & & & \\
Jackpot & 25940.4 & 2118.2 & 28965.6 & 11.66 & 30688.0 & 18.30 \\
$\quad$ Static & 26152.6 & 2520.7 & 30184.8 & 15.42 & 32539.3 & 24.42 \\
Dynamic & & & & & & \\
& & & & & & \\
Effective price & 26315.8 & 2345.9 & 25923.1 & -1.49 & 25433.2 & -3.35 \\
$\quad$ Static & 26633.0 & 2791.4 & 26119.2 & -1.93 & 25486.8 & -4.30 \\
Dynamic & & & & & & \\
\hline
\end{tabular}


Table A.1: Descriptive statistics

\begin{tabular}{|c|c|c|c|c|c|c|}
\hline & \multicolumn{2}{|c|}{$1972 / 73$ to $02 / 03$} & \multicolumn{2}{|c|}{ Pleno al $15=1$} & \multicolumn{2}{|c|}{ Price $=0.3 €$} \\
\hline & Mean & St. Dev. & Mean & St. Dev. & Mean & St. Dev. \\
\hline Sales (millions) & 61.314 & 34.957 & 36.101 & 12.145 & 38.995 & 8.868 \\
\hline Revenue (nominal) (million €) & 6.837 & 3.860 & 8.723 & 3.997 & 11.710 & 2.664 \\
\hline Revenue (real ${ }^{1}$ ) (million $€$ ) & 10.978 & 5.555 & 7.324 & 2.716 & 8.769 & 2.040 \\
\hline Nominal price (nominal) $(€)$ & 0.146 & 0.096 & 0.234 & 0.058 & 0.300 & 0.000 \\
\hline Nominal price $\left(\right.$ real $\left.^{1}\right)(€)$ & 0.186 & 0.036 & 0.201 & 0.024 & 0.225 & 0.011 \\
\hline Expected prize (nominal) $(€)$ & 0.079 & 0.053 & 0.127 & 0.035 & 0.164 & 0.020 \\
\hline Expected prize $\left(\right.$ real $\left.^{1}\right)(€)$ & 0.101 & 0.022 & 0.109 & 0.017 & 0.122 & 0.015 \\
\hline Effective price (nominal) $(€)$ & 0.067 & 0.045 & 0.107 & 0.030 & 0.137 & 0.020 \\
\hline Effective price $\left(\right.$ real $\left.^{1}\right)(€)$ & 0.085 & 0.018 & 0.092 & 0.016 & 0.102 & 0.016 \\
\hline Rollover (nominal) (million $€)^{2}$ & 1.458 & 1.075 & 1.458 & 1.075 & 1.807 & 1.131 \\
\hline Rollover $\left(\right.$ real $\left.^{1}\right)(\text { million } €)^{2}$ & 1.220 & 0.838 & 1.220 & 0.838 & 1.348 & 0.844 \\
\hline Jackpot (nominal) (million €) & 1.671 & 1.333 & 2.495 & 1.457 & 3.373 & 1.323 \\
\hline Jackpot $\left(\right.$ real $\left.^{1}\right)$ (million $\left.€\right)$ & 2.356 & 1.078 & 2.094 & 1.075 & 2.524 & 0.995 \\
\hline Lotería Primitiva & 0.575 & & 1.000 & & 1.000 & \\
\hline Absence of 1st Division teams & 0.129 & & 0.076 & & 0.095 & \\
\hline Absence of $2^{\text {nd }}$ Division teams & 0.070 & & 0.041 & & 0.081 & \\
\hline Pleno al 15 & 0.481 & & 1.000 & & 1.000 & \\
\hline Easter week & 0.025 & & 0.025 & & 0.024 & \\
\hline
\end{tabular}




\begin{tabular}{llll}
\hline Midweek fixture & 0.011 & 0.018 & 0.028 \\
Fixture 1 & 0.025 & 0.025 & 0.024 \\
Fixture 2 & 0.025 & 0.025 & 0.024 \\
Draw & 0.003 & & 0.000 \\
Month: & & 0.110 & 0.109 \\
January & 0.109 & 0.100 & 0.100 \\
February & 0.100 & 0.109 & 0.100 \\
March & 0.107 & 0.109 & 0.109 \\
April & 0.106 & 0.097 & 0.095 \\
May & 0.103 & 0.051 & 0.066 \\
June & 0.055 & 0.008 & 0.019 \\
August & 0.006 & 0.107 & 0.104 \\
September & 0.105 & 0.115 & 0.109 \\
October & 0.111 & 0.105 & 0.104 \\
November & 0.106 & 0.089 & 0.085 \\
December & 0.093 & 608 & 211 \\
\hline Number of observations & 1265 & \\
\hline
\end{tabular}

Notes: $\quad{ }^{1}$ Variables in real terms

${ }^{2}$ Dummy variables (equal to 1 when the observation has a particular attribute associated to the dummy and equal 0 otherwise) 
${ }^{1}$ Spanish National Organization for the Blind.

${ }^{2}$ See Clotfelter and Cook (1990), Walker (1998) and Forrest and Simmons (2003) for surveys of this literature.

${ }^{3}$ See Cook and Clotfelter (1993), Gulley and Scott (1993), Scott and Gulley (1995), Walker (1998), Farrell et al (1999) and Forrest et al (2000) as examples of empirical applications of the effective price model to for the analysis of the determinants of lotto sales.

${ }^{4}$ Farrell et al (2000) show that if the choice is not random but conscious, like in La Quiniela, the basic results of the effective price model are not changed.

${ }^{5}$ Forrest et al (2002) refer to a superdraw in the British lotto which was added to the second prize, reducing consequently the effective price, but surprisingly sales decreased $7.1 \%$ with respect to the previous draw.

${ }^{6}$ See Garrett and Sobel (1999) and Walker and Young (2001) for empirical applications where the third moments of the expected prizes are included in the demand equations.

${ }^{7}$ Beenstock and Szpiro (2002) propose a genetic algorithm to estimate this model taking into account the non-linearity generated by the definition of both variables.

${ }^{8}$ We do not present the estimates of the model for the sample previous to the appearance of the Loteria Primitiva and the Pleno al 15 because there were no rollovers and, consequently, we could not estimate the model by IV. 
${ }^{9}$ This reduction is less important if the coupon includes Second Division teams.

${ }^{10}$ This explains why the clubs' association receives $10 \%$ of the revenue generated by La Quiniela and, possibly, why they are asking to increase this percentage.

${ }^{11}$ We did not obtain a significant effect on sales of the change introduced by ONLAE when including a prize for those correctly guessing all the results at half time (1986-87 and $1987-88$ seasons).

${ }^{12}$ García and Rodríguez (2002) obtain similar results for this variable when analysing the determinants of attendance in the Spanish football league. Midweek fixtures have a negative effect on football-related demands.

${ }^{13}$ See Purfield and Waldron (1999) and Forrest et al (2004) for empirical analysis of the complementarity/substitutability between different lottery games. 